\title{
Correction to: Low-wage migrant workers during coronavirus disease 2019: a social determinants analysis
}

\author{
Amarasinghe Arachchige Don Nalin Samandika Saparamadu ${ }^{1,6}$. \\ Albie Sharpe ${ }^{2}$ Sun Kim ${ }^{3}$ Bruna Ligia Ferreira Almeida Barbosa ${ }^{4}$. \\ Adrian Pereira ${ }^{5}$
}

Published online: 1 October 2021

๑) Springer Nature Limited 2021

\section{Correction to: J Public Health Policy (2021) 42:452-464 https://doi.org/10.1057/s41271-021-00303-z}

Due to an unfortunate oversight during the copy editing a sentence in paragraph 'South Korea: beyond the COVID-19 pandemic' has been given erroneously:

'Although Korea having ratified the GCM (unlike Singapore and Brazil), wage parity with local residents has remained.'

It should be read as follows: 'Despite Korea having ratified the GCM (unlike Singapore and Brazil), wage parity with local residents has remained elusive.'

The original article has been corrected.

Publisher's Note Springer Nature remains neutral with regard to jurisdictional claims in published maps and institutional affiliations.

The original article can be found online at https://doi.org/10.1057/s41271-021-00303-z.

Amarasinghe Arachchige Don Nalin Samandika Saparamadu

samandika@icloud.com

1 Doctor Anywhere Pte. Ltd., 30A Kallang Place, \#11-06, Singapore 339213, Singapore

2 School of Public Health, The University of Technology, Sydney, 15 Broadway, Ultimo, NSW 2007, Australia

3 Health Policy Research Center, People's Health Institute, Sadangro 13-gil 36, 2nd floor, Dongjak-gu, Seoul 07004, South Korea

4 Federal University of Espirito Santo, Marechal Campos 1468, Vitoria, ES, Brazil

5 North South Initiative, A-2-7 Pusat Perdagangan Seksyen 8, Jalan Sg Jernih 8/1, 46050 Petaling Jaya, Selangor, Malaysia

673 Oxley Rise, The Rise @ Oxley, \#10-12, Singapore 238699, Singapore

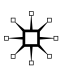


Amarasinghe Arachchige Don Nalin Samandika Saparamadu MBBS, DipIBLM, is a General Practitioner at Doctor Anywhere Pte. Ltd., Singapore.

Albie Sharpe MHID, Ph.D., is a Lecturer at the School of Public Health, The University of Technology Sydney, Australia.

Sun Kim M.S., Ph.D., is Director, Health Policy Research Center, People's Health Institute, Seoul, South Korea.

Bruna Ligia Ferreira Almeida Barbosa MNS, Ph.D., Postgraduate Program of Collective Health, Federal University of Espirito Santo, Vitoria, Brazil.

Adrian Pereira B. Eng, is Executive Director of the North South Initiative, Selangor, Malaysia. 